\title{
Glutamine Synthetase II Constitutes a Novel Taxonomic Marker in Rhizobium etli and Other Rhizobium Species
}

\author{
HERMENEGILDO TABOADA, ${ }^{1}$ SERGIO ENCARNACIÓN, ${ }^{1}$ MARÍA DEL CARMEN VARGAS, ${ }^{1}$ \\ YOLANDA MORA,${ }^{1}$ ESPERANZA MARTÍNEZ-ROMERO ${ }^{2}$ AND JAIME MORA ${ }^{1 *}$ \\ Departamento de Ecología Molecular, ${ }^{1}$ and Departamento de Genética Molecular, ${ }^{2}$ \\ Centro de Investigación sobre Fijación de Nitrógeno, Universidad Nacional \\ Autónoma de México, Cuernavaca, Morelos, Mexico
}

\begin{abstract}
Different Rhizobium species may be identified by using polymorphisms in their glutamine synthetases (GSII) but not by their GSI profiles. We analyzed the GSs of various Rhizobium tropici and Rhizobium etli strains (which are capable of nodulating and fixing nitrogen in Phaseolus vulgaris beans), as well as strains of other species included for comparison. The GS polymorphisms were determined by identifying variations in native enzyme mobility (revealed by GS activity staining) and in the isoelectric points of the monomers (revealed by immunodetection with antibodies against the GS proteins) by using gel electrophoresis. Restriction fragment length polymorphism patterns obtained by hybridizing an internal fragment of the GSII gene obtained from $R$. etli with total fragmented DNAs from different strains clearly distinguished the different groups. GSII is a novel and useful marker for Rhizobium groups and species, and GSII data support $R$. tropici and $R$. etli as bona fide species.
\end{abstract}

Glutamine synthetases (GSs), which are key enzymes in nitrogen metabolism, are ubiquitous and well-conserved enzymes. Different GSs (e.g., GSI and GSII) which differ in their primary and tertiary structures have been described. GSI and GSII seem to have resulted from a duplication event early in evolution (56) that preceded the split of the Archaeobacteria and Eubacteria (46) or the split of the prokaryotes and eukaryotes (30). Very few prokaryotes have two GS isoenzymes; two prokaryote genera whose members have two GS isoenzymes are the genera Rhizobium $(12,14,52,56)$ and Agrobacterium (22).

Rhizobium species have attracted a great deal of research interest because of their capacity to fix nitrogen in legume root nodules. In Rhizobium strains, GSs are central enzymes in nitrogen metabolism and, together with glutamate synthase, are responsible for ammonium assimilation (10). GSI and GSII have different roles in symbiotic and free-living bacteria (reviewed in reference 21 ). Only GSI activity has been detected in symbiotic bacteria $(42,57)$. GSI is present in bacteria growing in rich medium, and GSII is present in minimal medium cultures. We have also found that GSI activity is related to a pseudofermentative metabolism and that GSII activity is found mainly during aerobic metabolism in Rhizobium strains (19, 20). The individual contributions of GSI and GSII to glutamine synthesis depend on fine regulatory mechanisms that affect the expression of the respective genes $(1,37,44)$ or the enzymatic activities $(6,26,34,35,49,57)$.

The genus Rhizobium is a heterogeneous group of bacteria, and recently our knowledge of the scope of the diversity of Rhizobium species has increased because many strains isolated from different hosts have been analyzed (33). At the present time the most reliable method for characterizing and identifying strains is analysis of ribosomal gene sequences. These sequences have become the universal reference criteria for defining bacterial phylogenies (61), and data obtained from

\footnotetext{
* Corresponding author. Mailing address: Departamento de Ecología Molecular, Centro de Investigación sobre Fijación de Nitrógeno, Apdo. postal 565-A, Cuernavaca, Morelos, Mexico. Fax: (73) 175094. Electronic mail address: jmora@cifn.unam.mx.
}

partial or complete 16S rRNA sequences have been essential in proposing new Rhizobium species, such as Rhizobium etli (55) and Rhizobium tropici (40). $R$. etli has been isolated from Phaseolus vulgaris bean nodules in Mesoamerica, and $R$. tropici has been isolated from bean and Leucaena nodules obtained from South American acid soils. Both of these species are broad-host-range rhizobia that nodulate many hosts in addition to bean and Leucaena species (25). Originally, $R$. etli was classified as Rhizobium leguminosarum bv. phaseoli (type I), but on the basis of the sequence of fragments of ribosomal genes, $R$. etli was recognized as a chromosome lineage that was distinct from $R$. leguminosarum.

Recent results challenge the validity of single-gene-based phylogenies in the genus Rhizobium (17) and in other bacteria (8) and point out the need to consider additional markers. It has been recognized that polyphasic characterization would contribute to validation of the present Rhizobium taxonomy $(24,33,39)$. The results of polyacrylamide gel electrophoresis of total proteins (15) and repetitive extragenic PCR characterization (13) allow workers to group Rhizobium strains. The identification of additional useful markers would be valuable in Rhizobium systematics. GSs are good candidates for this since they behave as ideal molecular clocks (45) to trace evolution, and very reliable genetic distances among organisms have been estimated with the data obtained $(30,46)$.

The aim of this study was to characterize GSI and GSII in different Rhizobium species, with special emphasis on $R$. etli and $R$. tropici strains, to further validate the taxonomic position of these organisms. We found that GSII provides a novel marker for groups and species belonging to the genus Rhizobium, while GSI is conserved in all of the species tested.

\section{MATERIALS AND METHODS}

Bacterial strains and growth conditions. The bacterial strains which we used are listed in Table 1. Rhizobium strains were grown in PY medium or minimal medium (7). Minimal medium contained $10 \mathrm{mM}$ succinate and $10 \mathrm{mM}$ potassium nitrate supplemented as described previously (7). Extracts of the different Rhizobium species were obtained from $150 \mathrm{ml}$ of PY medium or minimal medium batch cultures grown in $250-\mathrm{ml}$ Erlenmeyer flasks. Escherichia coli was grown in Luria broth.

GS purification. GSI and GSII were purified from cultures of $R$. etli $\mathrm{CFN} 42^{\mathrm{T}}$ 
TABLE 1. Bacterial strains

\begin{tabular}{|c|c|c|}
\hline Strain & Original host plant and/or relevant characteristics & Source or reference ${ }^{a}$ \\
\hline \multicolumn{3}{|l|}{$R$. etli strains } \\
\hline $\mathrm{CFN} 42^{\mathrm{T}}$ & P. vulgaris L. from Guanajuato, Mexico, wild-type reference strain & 55 \\
\hline CFN277 & $P$. vulgaris L. from Jalisco, Mexico & 38 \\
\hline CFN279 & P. vulgaris L. from Hidalgo, Mexico & 38 \\
\hline CFN403 & P. vulgaris L. from Tepoztlán, Morelos, Mexico & Martínez \\
\hline Nitragin 8251 & $P$. vulgaris $\mathrm{L}$. & 47 \\
\hline Viking 1 & P. vulgaris L. from Belize & 47 \\
\hline Bra-5 & P. vulgaris L. from Brazil & 47 \\
\hline F-17 & P. vulgaris L. from Tepoztlán, Morelos, Mexico & 47 \\
\hline CFN3 & P. vulgaris L. from Guanajuato, Mexico & 47 \\
\hline R. leguminosarum bv. viciae VF39 & Vicia faba from Bielefeld, Germany & 48 \\
\hline \multicolumn{3}{|l|}{ R. leguminosarum bv. trifolii strains } \\
\hline TA1 & Trifolium repens from Australia & 53 \\
\hline ANU843 & Wild type, $\mathrm{Nod}^{+} \mathrm{Fix}^{+}$on white and subterranean clovers & 51 \\
\hline \multicolumn{3}{|l|}{ R. leguminosarum bv. phaseoli strains } \\
\hline Sp18 & P. vulgaris L. from England & Young \\
\hline M1928 & P. vulgaris L. from England & Young \\
\hline 248 & $P$. vulgaris L. from England & Brewin \\
\hline R. fredii USDA 193 & Glycine $\max$ & USDA \\
\hline \multicolumn{3}{|l|}{ R. meliloti strains } \\
\hline 2011 & Alfalfa, wild type & INRA \\
\hline 1021 & Streptomycin resistant, from 2011 & 41 \\
\hline $104 \mathrm{~A} 14$ & Alfalfa, wild type & 57 \\
\hline R.me2 & Alfalfa from Guanajuato, Mexico & Martínez \\
\hline R.me8 & Alfalfa from Guanajuato, Mexico & Martínez \\
\hline \multicolumn{3}{|l|}{ R. tropici type A strains } \\
\hline CFN299 & P. vulgaris L., wild-type reference strain & 40 \\
\hline BR845 & Leucaena leucocephala from Brazil & 40 \\
\hline BR846 & L. leucocephala from Brazil & 40 \\
\hline BR10042 & P. vulgaris L. from Brazil & 40 \\
\hline BR10043 & P. vulgaris L. from Brazil & 40 \\
\hline C-05-1 & P. vulgaris L. from Brazil & 40 \\
\hline \multicolumn{3}{|l|}{ R. tropici type B strains } \\
\hline CIAT $899^{\mathrm{T}}$ & P. vulgaris L., wild-type reference strain & 40 \\
\hline BR852 & L. leucocephala from Brazil & 40 \\
\hline BR853 & L. leucocephala from Brazil & 40 \\
\hline BR857 & L. leucocephala from Brazil & 40 \\
\hline BR863 & L. leucocephala from Brazil & 40 \\
\hline Rhizobium sp. strain OR191 & Alfalfa, ineffective nodules from Oregon & 18 \\
\hline \multicolumn{3}{|l|}{ B. japonicum strains } \\
\hline $\mathrm{CJ} 1$ & Soybean & 36 \\
\hline USDA110 & Soybean & USDA \\
\hline E. coli $\mathrm{MX} 727$ & & 4 \\
\hline
\end{tabular}

${ }^{a}$ Brewin, N. J. Brewin, John Innes Institute, Norwich, United Kingdom; Young, J. P. W. Young, Department of Biology, University of York, Heslington, York, United Kingdom; INRA, Laboratoire de Biologie Moléculaire des Relations Plantes-Microorganismes, Centre National de la Recherche Scientifique, Institut National de la Recherche Agronomique, Castanet-Tolosan, Toulouse, France; USDA, Rhizobium Culture Collection, Beltsville Agricultural Research Center, U.S. Department of Agriculture, Beltsville, Md., Martínez, E. Martínez Centro de Investigación sobre Fijación de Nitrógen, Universidad Nacional Autónoma de México, Cuernavaca, Morelos, Mexico.

( $\mathrm{T}=$ type strain). To isolate GSII, bacteria were grown for $10 \mathrm{~h}$ in shaken minimal medium cultures at $30^{\circ} \mathrm{C}$. Pellets were obtained from 5 liters of culture by centrifugation, washed, and suspended in $400 \mathrm{ml}$ of $10 \mathrm{mM}$ imidazole $-1 \mathrm{mM}$ manganese chloride buffer ( $\mathrm{pH} 7$ ) (buffer A). Extracts were obtained by sonicating preparations with a Soniprep 150 apparatus (MSE) in an ice water bath by using 10 1-min pulses interrupted by 3-min cooling periods, using a macrotip. The extracts were centrifuged at $12,000 \times g$ for $15 \mathrm{~min}$ at $5^{\circ} \mathrm{C}$. The clear supernatants obtained were precipitated by adding solid ammonium sulfate to concentration that was $35 \%$ of the saturation concentration. After centrifugation, the supernatant was recovered, and ammonium sulfate was added to a concentration that was $55 \%$ of the saturation concentration. The pellet recovered after centrifugation was dissolved in $10 \mathrm{mM}$ imidazole $-5 \mathrm{mM}$ manganese chloride buffer ( $\mathrm{pH}$ 6.8) (buffer B), dialyzed against the same buffer, and chromatographed on a Reactive Blue 2-Sepharose CL-6B (Sigma) column. The column was eluted with $5.3 \mathrm{mM}$ ADP in buffer $\mathrm{B}$, and fractions were assayed for GS transferase activity (5). The fractions with the highest activities were pooled, loaded onto a QMA/ACCEL ion-exchange high-performance liquid chromatography (HPLC) column, and eluted with a linear 0 to $1 \mathrm{M} \mathrm{KCl}$ gradient for $30 \mathrm{~min}$ The fractions with the highest activity were loaded onto a preparative Laemml protein gel (31). A prestained molecular weight standard mixture (molecular weight range, 34,000 to 191,000 ) obtained from Sigma was used as a reference. A $40-\mathrm{kDa}$ band corresponding to GSII was recovered from the gel.

GSI was purified from 5 liters of a CFN42 ${ }^{\mathrm{T}}$ culture growing in PY medium. Clear extracts were obtained by the procedure described above. Before the ammonium sulfate precipitation step, the supernatants were warmed for $1 \mathrm{~h}$ at $50^{\circ} \mathrm{C}$ followed by centrifugation. Protein was precipitated with ammonium sulfate to a final concentration that was $70 \%$ of the saturation concentration, and the pellet was dialyzed against buffer $\mathrm{A}$ and chromatographed with a Reactive Blue 2-Sepharose CL-6B column as described above, except that washing and elution were with buffer A instead of buffer B. HPLC purification and Laemmli polyacrylamide electrophoresis were performed as described above for GSII purification, but a $50-\mathrm{kDa}$ band corresponding to GSI was isolated.

Anti-GS antibodies. GSII and GSI were recovered from Laemmli gels in a sterile saline $(0.85 \% \mathrm{NaCl})$ solution, mixed with Freund adjuvant, and used for subcutaneous rabbit immunization every week for 6 weeks. The antibody titer was determined by serially diluting the serum. The optimal dilutions were $1: 8,000$ with anti-GSI serum and 1:6,000 with anti-GSII serum when we used $10 \mu \mathrm{g}$ of total protein extract in Western blots (immunoblots) (see below). No crossreactivity was observed with anti-GSII serum and purified GSI. Anti-GSI serum did not react with purified GSII. Only specific reactions in which single spots 


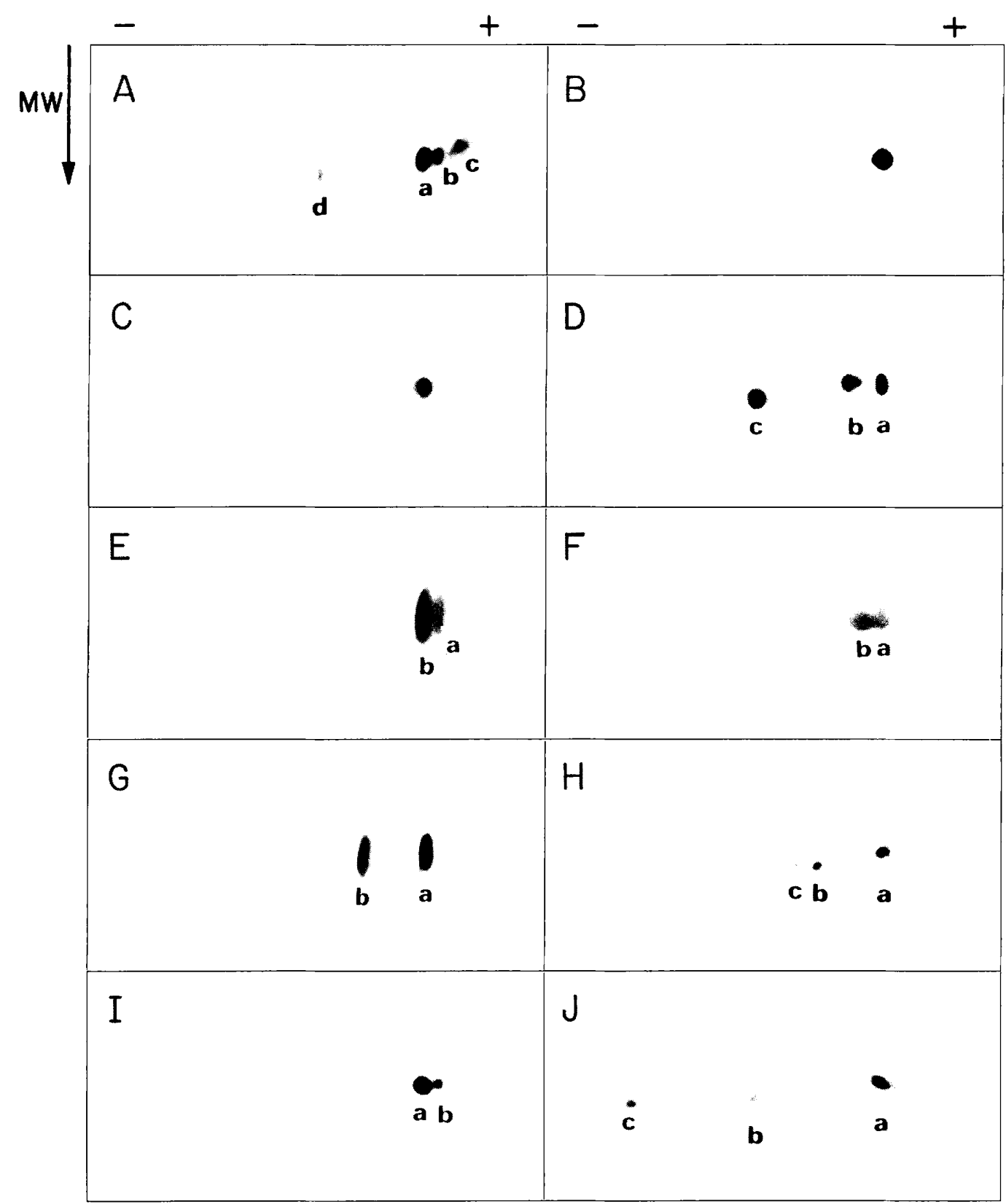

FIG. 1. Immunodetection of GSII in blots of two-dimensional protein gels prepared with different Rhizobium strains. (A) R. etli CFN42 ${ }^{\mathrm{T}}$ (spot a), R. tropici BR846 (spot b), R. tropici BR852 (spot c), and R. meliloti R.me8 (spot d). (B) R. etli CFN42 ${ }^{\mathrm{T}}$, Nitragin 8251, and CFN403. (C) R. etli CFN42 ${ }^{\mathrm{T}}$ and Rhizobitum sp. strain OR191. (D) R. etli Bra5 (spot a), R. leguminosarum bv, trifolii TAl and ANU 843 (spot b), and R. meliloti R.me8 (spot c). (E) R. etli CFN42 ${ }^{\mathrm{T}}$ (spot a) and $R$. leguminosarum bv. phaseoli Sp18 (spot b). (F) R. etli CFN $42^{\mathrm{T}}$ (spot a) and R. leguminosarum bv, phaseoli M1928 (spot b). (G) R. etli CFN42 (spot a) and $R$. leguminosarum bv, phaseoli 248 (spot b). (H) R. etli CFN42 (spot a), R. meliloti 104A14 (spot b), and R. meliloti 1021 (spot c). (I) R. meliloti 1021 (spot a) and R. fredii USDA193 (spot b). (J) R. etli Bra5 (spot a), R. meliloti R.me2 (spot b), and B. japonicum CJ1 (spot c). MW, molecular weight.

were observed were obtained. The negative control used consisted of serum obtained before the immunization procedure was performed.

GS electrophoresis. GS activity was detected by the transferase assay (5) in nondenaturating polyacrylamide $(4$ to $8 \%$ ) continuous gels. To determine the isoelectric points, bacterial extracts were electrophoresed in two-dimensional gels as described by O'Farrell (43). Isoelectric focusing was performed in the first dimension with $2 \%(\mathrm{vol} / \mathrm{vol})$ ampholines (Pharmacia LKB); the $\mathrm{pH}$ ranges used were $\mathrm{pH} 3.5$ to 10 and $\mathrm{pH} 5$ to 7 (in cylindrical acrylamide gels). Isoelectric focusing markers ( $\mathrm{pH}$ range, 3.6 to 9.3) were obtained from Sigma. Proteins were separated in the second dimension mainly by their molecular weights.

GS immunodetection. O'Farrell protein gels were blotted onto Schleicher \& Schuell nitrocellulose membranes (59), and the membranes were processed as described by Walker and Gaastra (60). Enzymatic detection of membrane-bound antigens was performed by using alkaline phosphatase-conjugated goat anti- rabbit immunoglobulin G (Sigma). Nitro Blue Tetrazolium and 5-bromo-4chloro-3-indolylphosphate were used as the substrates.

DNA-DNA hybridization. pCV002 is pBR322 (9) containing a 7-kb cloned fragment from $R$. etli CFN42 ${ }^{\mathrm{T}}$ isolated from a library of Sau3A fragments obtained by partial digestion. pCV002 was selected from a pool of clones that hybridized to a 2.1-kb insertion obtained from pBJ196A, which contains GSII gene from Bradyrhizobium japonicum (11). pCV002 was identified by its ability to complement $E$. coli GS mutant MX727 (glnA21::Tn5 [4]) for growth in minimal medium because the GS enzymatic activity is restored. A $0.5-\mathrm{kb}$ SalI-BglIII fragment (in the GSII gene) was identified from pCV002 by hybridization with a 30-bp oligonucleotide (5'-CCGACCTCCGGTTATCCGGCGCCGCAGGGC$\left.3^{\prime}\right)$ on the basis of the $B$. japonicum GSII gene sequence, labelled with $\left[\gamma_{-}{ }^{32} \mathrm{P}\right] \mathrm{ATP}$ as described previously (3). The $0.5-\mathrm{kb}$ fragment was purified, labelled with $\left[{ }^{32} \mathrm{P}\right] \mathrm{dCTP}$ by nick translation $(50)$, and used as a probe. Total DNAs 


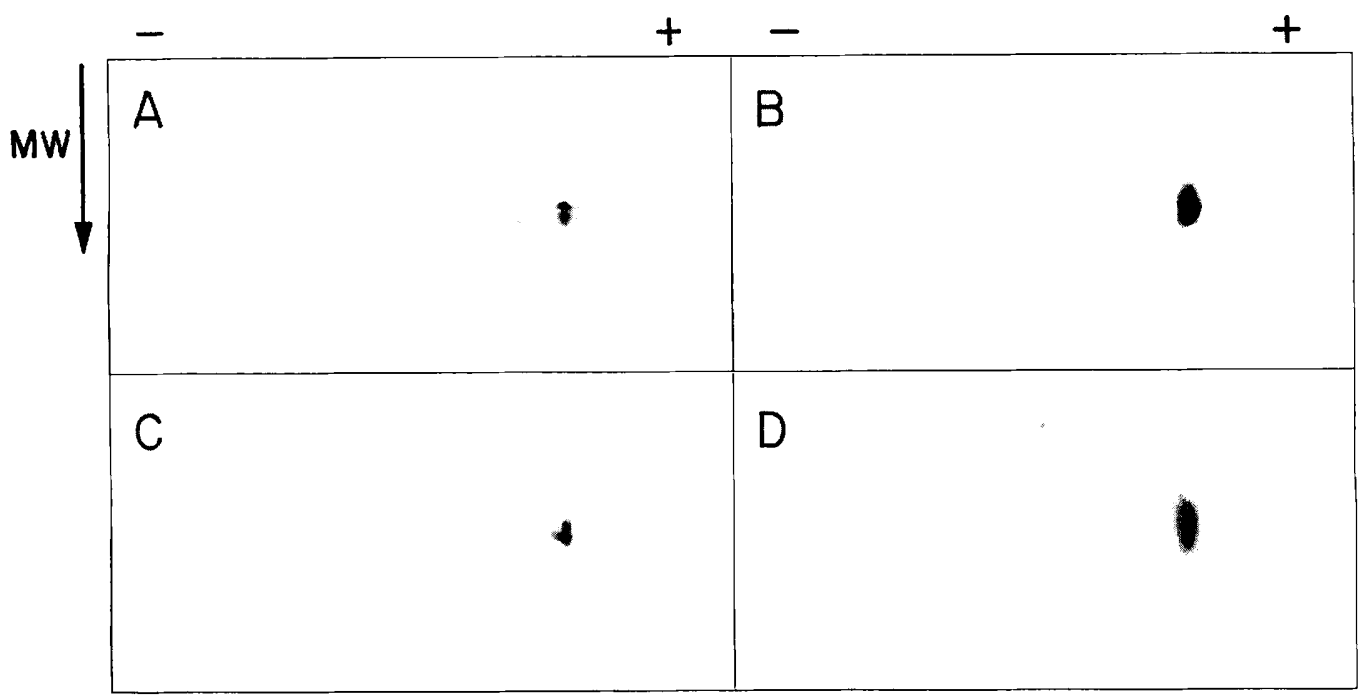

FIG. 2. Immunodetection of GSI as described in the legend to Fig. 1. (A) R. etli CFN42 ${ }^{\mathrm{T}}$ and R. tropici $\mathrm{C}-05-1$ and BR852. (B) R. etli CFN42 ${ }^{\mathrm{T}}$ and $R$. meliloti 1021 . (C) R. etli CFN42 $2^{\mathrm{T}}$ and $R$. leguminosarum bv. trifolii ANU843. (D) $R$. etli $\mathrm{CFN} 42^{\mathrm{T}}$ and B. japonicum USDA110. MW, molecular weight.

from different Rhizobium strains were purified as described previously (3). SalI or $X h o I$ digests were electrophoresed in agarose gels, and blot transfers were hybridized under high-stringency conditions to the $0.5-\mathrm{kb}$ fragment obtained from pCV002, which was prepared by the alkaline lysis method (3). Hybridization signals were detected by autoradiography.

\section{RESULTS}

GS enzyme electrophoresis. As a first approach to characterizing Rhizobium GSII, the mobility variants of the native enzymes obtained from several $R$. etli, $R$. tropici, and $R$. meliloti strains were identified by the GS transferase assay on onedimensional gels. A single band was produced by all of the $R$. etli strains tested (CFN42 ${ }^{\mathrm{T}}$, CFN3, F-17, Viking 1, Nitragin 8251 ), another band with a different mobility was produced by all of the $R$. tropici strains analyzed (CIAT899 ${ }^{\mathrm{T}}$, CFN299, C-05-I, C-05-II), and a third mobility variant was produced by the Rhizobium meliloti strains (2011, R.me2, R.me8). Therefore, GSII was monomorphic in each of the species tested, and these species could be distinguished by the mobilities of their native GSII enzymes. These first results obtained with only three species were considered the basis for a more complete analysis of GSs in which we used the molecular weights and isoelectric points of the GSs of a larger number of $R$. etli and $R$. tropici strains and strains of other Rhizobium species.

GSII isoelectric points determined by Western blotting. GSs are oligomeric enzymes that consist of identical monomers or subunits. A very fine method for exploring enzyme polymorphism is determining the isoelectric points of the monomers, and this was accomplished by performing an immunodetection analysis of GSII in two-dimensional O'Farrell gels (43). To compare the GSs of different strains, we coelectrophoresed extracts of the strains, and the results of some of our experiments are shown in Fig. 1. The results obtained with $R$. tropici, R. etli, and R. meliloti GSII isoforms are shown in Fig. 1A. Each species has a distinct monomer. Even though the GSII mobility variants of all $R$. tropici strains were identical on one-dimensional native gels, the GSII isoenzymes of $R$. tropici type A strains CFN299, BR845, BR846, and BR10043 were different from the GSII isoenzymes of $R$. tropici type B strains CIAT899 $^{\mathrm{T}}$, BR852, BR857, and BR863 on the two-dimensional gels. The $R$. etli strains tested $\left(\mathrm{CFN} 42^{\mathrm{T}}\right.$, Viking 1 , CFN279, Nitragin 8251, Bra5, and CFN403) all had identical isoforms (the results obtained with some of these strains are shown in Fig. 1B), which were also identical to the GSII isoenzyme of Rhizobium sp. strain OR191 (Fig. 1C).

Our results showed that $R$. etli has a different GSII isoform than $R$. leguminosarum bv. phaseoli SP18 (Fig. 1E), M1928 (Fig. 1F), and 248 (Fig. 1G), R. leguminosarium bv. trifolii ANU843 and TA1 (Fig. 1D), and R. leguminosarum bv. viciae VF39 (data not shown).

Two different types of $R$. meliloti have been identified (16). When the $g \ln I I$ (GSII gene) hybridization patterns obtained for some $R$. meliloti strains were analyzed, $R$. meliloti 104A14 was the only one of five $R$. meliloti strains that had a distinctive profile (57). We also found that $R$. meliloti $104 \mathrm{~A} 14$ had a different GSII monomer than $R$. meliloti 1021 (Fig. $1 \mathrm{H}$ ). The GSIIs of $R$. meliloti 1021, 2011, R.me8, and R.me2 had identical isoelectric points (data not shown). Rhizobium fredii USDA193 had a GSII isoform that was similar but not identical to the GSII isoforms of the $R$. meliloti strains (Fig. 1I).

The most different GSII monomer was the GSII monomer of Bradyrhizobium japonicum $\mathrm{CJ} 1$, and this finding is consistent with the separation of the genera Rhizobium and Bradyrhizobium (reviewed in reference 39 ).

GSI isoelectric point. In contrast to the results obtained with GSII, GSI was conserved in all of the Rhizobium species tested, and these organisms could not be distinguished by their GSI isoenzymes. $R$. etli, $R$. tropici, $R$. meliloti, and B. japonicum strains had GSIs with identical or very similar isoelectric points (Fig. 2).

Restriction fragment length polymorphism of GSII genes. To complement our GS characterization of different Rhizobium strains, we analyzed GSII gene restriction fragment length polymorphism patterns. Each of the Rhizobium species tested produced a characteristic pattern (Fig. 3), and the patterns obtained from $R$. tropici type A strains were different from the patterns obtained from $R$. tropici type B strains.

\section{DISCUSSION}

We characterized the GSIs and GSIIs of a number of Rhizobium strains, and we found that GSII is a novel marker that can be used for identification of Rhizobium species. We gave special emphasis to the species that nodulate beans, $R$. etli (55) 


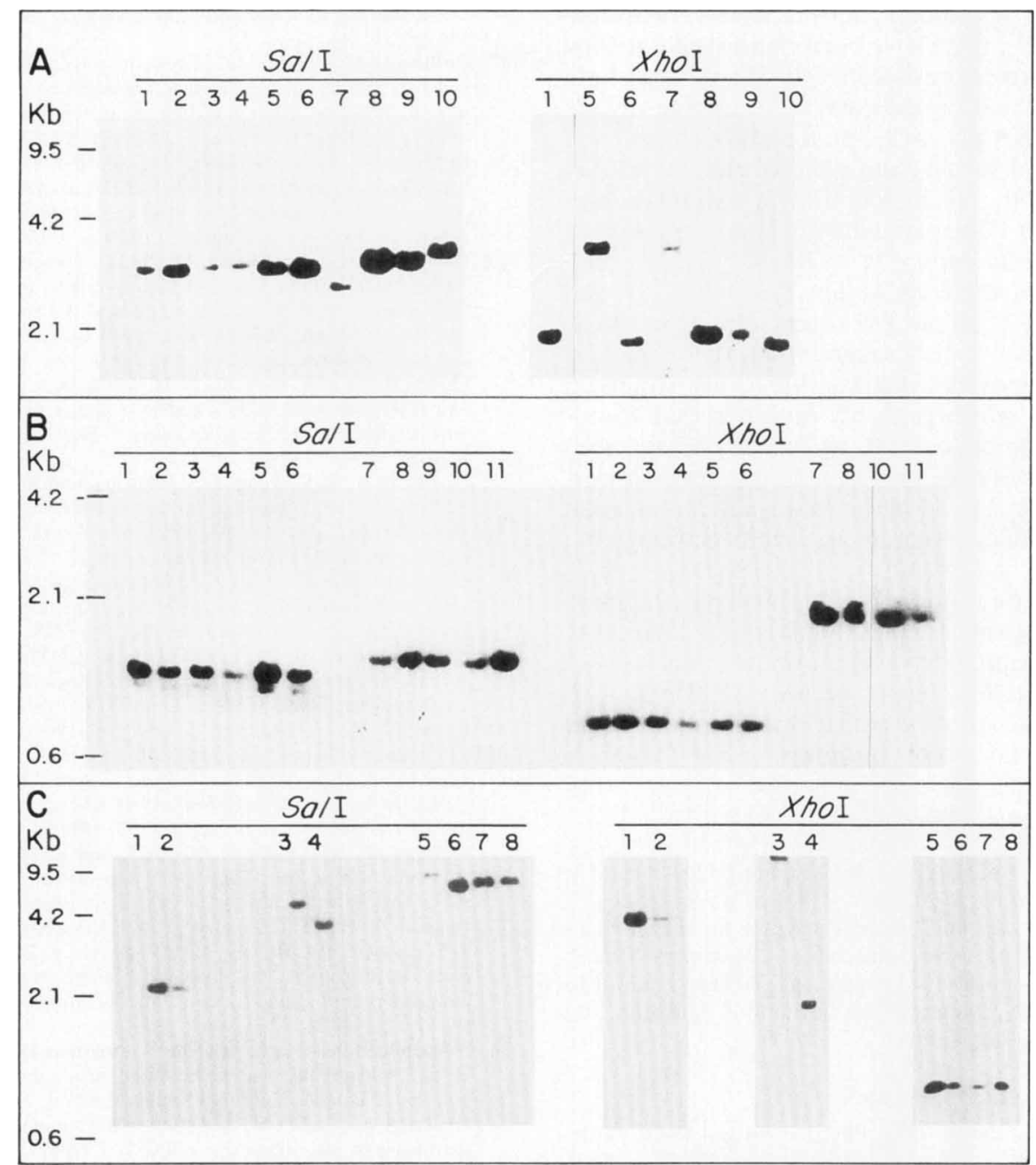

FIG. 3. Southern blots of total genomic DNAs of several Rhizobium species hybridized with a 0.5 -kb glnII (GSII gene) internal fragment. The endonucleases used in each experiment are indicated on the figure. (A) R. etli strains. Lanes 1 and 2, CFN42T; lane 3, CFN279; lane 4, F-17; lanes 5, Bra5; lanes 6, Viking 1; lanes 7, CFN3; lanes 8, CFN277; lanes 9, CFN403; lanes 10, Nitragin 8251. (B) Lanes 1 through 6, $R$. tropici type A strains BR845, CFN299, BR846, BR10043, BR10042, and C-05-1, respectively; lanes 7 through $11, R$. tropici type B strains BR852, BR857, BR863, BR853, and CIAT899 ${ }^{\mathrm{T}}$, respectively. (C) Lanes 1 and $2, B$. japonicum USDA 110 and CJ1, respectively; lanes 3 and 4, R. leguminosarum bv. trifolii ANU843 and TA1, respectively; lanes 5 through 8, R. meliloti R.me2, R.me8, 2011, and 1021, respectively.

and $R$. tropici (40), and our results support the recognition of these taxa as bona fide Rhizobium species.

Each of the Rhizobium species which we analyzed could be clearly distinguished by its GSII isoforms. One interpretation of our results is that each species is monophyletic, meaning that the strains of each Rhizobium species have a common ancestor. It has been proposed that differences in isoelectric points may make one isoenzyme better suited to a particular substrate or intracellular environment (27). Since different GSII isoenzymes are encountered in the distinct Rhizobium groups, we believe that GSIIs may reflect a functional and metabolic compromise that tightly links them to a whole set of other genes ("core Rhizobium genetic information") that determine the overall metabolic features of the divergent bacterial lineages.

The isoelectric points that we observed under our experimental conditions (data not shown) correspond to the following theoretical isoelectric points that we estimated from the previously reported GSII gene sequences $(11,56): 5.19$ for $R$. meliloti GSII enzymes and 6.51 for $B$. japonicum GSII enzymes. The amino acid compositions of the GSIIs of $R$. meliloti and $B$. japonicum are $91 \%$ identical, and only one-third of the different amino acids were responsible for the isoelectric points.

Our results are consistent with previously reported results. For example, Rhizobium sp. strain OR191 was isolated from ineffective alfalfa nodules in the United States and is capable of nodulating $P$. vulgaris, which is the normal symbiont of $R$. etli. On the basis of a partial sequence of its ribosomal genes, strain OR191 is closely related to $R$. etli (level of homology, $99 \%$ ) (18). The GSIIs of Rhizobium sp. strain OR191 and $R$. etli could not be distinguished by the results of isoelectric focusing (Fig. 1C). It has been observed previously that the differences between the two $R$. tropici types could be enough to reclassify them as different subspecies or even as different species (23). Our results, which show that the type A strain GSII is different from the GSII found in type B strains, support the subdivision of $R$. tropici. Although partial sequences of the 16S rRNA genes of $R$. fredii and $R$. meliloti are identical (28), these organisms can be distinguished both by the complete sequences of their $16 \mathrm{~S}$ rRNA genes and by their GSII isoforms. 
Several workers have described $R$. etli strains as very diverse $(17,47,54)$. $R$. etli and $R$. tropici have been clearly separated by multilocus enzyme electrophoresis data $(40,55)$, by their fatty acid compositions (29), and on the basis of restriction digests of PCR-synthesized rRNA genes $(2,32)$. Recently, some $R$. etli strains have been found to have an allele of the $16 \mathrm{~S}$ rRNA gene corresponding to the allele found in $R$. leguminosarum (17). This finding could be explained by a lateral transfer of rRNA genes from $R$. leguminosarum to $R$. etli (17). We analyzed one of the anomalous $R$. etli strains, Nitragin 8251 , and found that it produces a GSII pattern corresponding to the $R$. etli pattern. Recent results also suggest that there may be recombination of chromosomal markers in $R$. etli strains in local populations (58), which probably indicates that Rhizobium strains are not strictly clonal, as has been suggested previously (47). Thus, it is necessary to sample a broader portion of the genome to get a good image of it, and identification of additional markers linked to core genetic information in the bacteria is essential.

Although the procedure for determining isoelectric points is very laborious and not easily adapted for everyday laboratory screening of bacteria, it provides a way to pursue analyses of GSII genes in different Rhizobium species with the goal of developing gene-specific probes which would allow rapid screening of strains for taxonomic purposes.

\section{ACKNOWLEDGMENTS}

This work was supported by DGAPA-UNAM grant IN204489 and in part by DGAPA-UNAM grant IN202393.

We thank Verónica Narváez and Oscar Rodríguez for their collaboration at an early stage of this work and Julio C. Martínez-Romero and Michael Dunn for reviewing the manuscript. We are grateful to P. W. J. Young, B. Eardly, U. Priefer, P. van Berkum, F. de Bruijn, and F. O'Gara for kindly providing strains.

\section{REFERENCES}

1. Adams, T. M., and B. K. Chelm. 1988. Effects of oxygen levels on the transcription of nif and gln genes in Bradyrhizobium japonicum. J. Gen. Microbiol, 134:611-618.

2. Amarger, N., M. Bours, F. Revoy, M. R. Allard, and G. Laguerre. 1994. Rhizobium tropici nodulates field-grown Phaseolus vulgaris in France. Plant Soil 161:147-156.

3. Ausubel, F. M., R. Brent, R. Kingston, D. Moore, J. Smith, R. Siedman, and K. Strudel. 1994. Current protocols in molecular biology. Wiley Interscience, New York.

4. Bastarrachea, F., S. Brom, A. A. Covarrubias, A. Osorio, and F. Bolivar. 1980. Genetic characterization of mutations affecting glutamine biosynthesis and its regulation in Escherichia coli K12, p. 107-121. In J. Mora and R. Palacios, (ed.), Glutamine: metabolism, enzymology and regulation. Academic Press, New York.

5. Bender, R. A., K. A. Janssen, A. D. Resnick, M. Blumenberg, F. Foor, and B. Magasanik. 1977. Biochemical parameters of glutamine synthetase from Klebsiella aerogenes. J. Bacteriol. 129:1001-1009.

6. Bergersen, F. J., and G. L. Turner. 1978. Activity of nitrogenase and glutamine synthetase in relation to availability of oxygen in continuous cultures of a strain of cowpea Rhizobium sp. supplied with excess ammonium. Biochim. Biophys. Acta 538:406-416.

7. Beringer, J. E. 1974. R factor transfer in Rhizobium leguminosarum. J. Gen. Microbiol. 84: 188-198.

8. Bisercic, M., J. Y. Feutrier, and P. R. Reeves. 1991. Nucleotide sequences of the gnd genes from nine natural isolates of Escherichia coli: evidence of intragenic recombination as a contributing factor in the evolution of the polymorphic gnd locus. J. Bacteriol. 173:3894-3900.

9. Bolivar, F., R. L., Rodríguez, P. J. Greene, M. C. Betlach, H. L. Heynecker, and H. W. Boyer. 1977. Construction and characterization of new cloning vehicles. II. A multipurpose cloning system. Gene 2:95-113.

10. Bravo, A., and J. Mora. 1988. Ammonium assimilation in Rhizobium phaseoli by the glutamine synthetase-glutamate synthase pathway. J. Bacteriol. 170: 980-984.

11. Carlson, T. A., and B. K. Chelm. 1986. Apparent eukaryotic origin of glutamine synthetase II from the bacterium Bradyrhizobium japonicum. Nature (London) 322:568-570.

12. Darrow, R. A., and R. R. Knotts. 1977. Two forms of glutamine synthetase in free-living and root nodule bacteria. Biochem. Biophys. Res. Commun. 78: $554-559$.

13. De Bruijn, F. J. 1992. Use of repetitive (repetitive extragenic palindromic and enterobacterial repetitive intergeneric consensus) sequences and the polymerase chain reaction to fingerprint the genomes of Rhizobium meliloti isolates and other soil bacteria. Appl. Environ. Microbiol. 58:2180-2187.

14. De Bruijn, F. J., S. Rossbach, M. Schneider, P. Ratet, S. Messmer, W. W. Szeto, F. M. Ausubel, and J. Schell. 1989. Rhizobium meliloti 1021 has three differentially regulated loci involved in glutamine biosynthesis, none of which is essential for symbiotic nitrogen fixation. J. Bacteriol. 171:1673-1682.

15. De Lajudie, P., A. Willems, B. Pot, D. Dewettinck, G. Maestrojuan, M. Neyra, M. D. Collins, B. Dreyfus, K. Kersters, and M. Gillis. 1994. Polyphasic taxonomy of rhizobia: emendation of the genus Sinorhizobium and description of Sinorhizobium meliloti comb. nov., Sinorhizobium saheli sp. nov., and Sinorhizobium teranga sp. nov. Int. J. Syst. Bacteriol. 44:715-733.

16. Eardly, B. D., L. A. Materon, N. H. Smith, D. A. Johnson, M. D. Rumbaugh, and R. K. Selander. 1990. Genetic structure of natural populations of the nitrogen-fixing bacterium Rhizobium meliloti. Appl. Environ. Microbiol. 56: 187-194.

17. Eardly, B. D., F.-S. Wang, T. S. Whittam, and R. K. Selander. 1995. Species limits in Rhizobium populations that nodulate the common bean (Phaseolus vulgaris). Appl. Environ. Microbiol. 61:507-512.

18. Eardly, B. D., J. P. W. Young, and R. K. Selander. 1992. Phylogenetic position of Rhizobium sp. strain Or 191, a symbiont of both Medicago sativa and Phaseolus vulgaris, based on partial sequences of the $16 \mathrm{~S}$ rRNA and nifH genes. Appl. Environ. Microbiol. 58:1809-1815.

19. Encarnación, S., M. Dunn, K. Willms, and J. Mora. 1995. Fermentative and aerobic metabolism in Rhizobium etli. J. Bacteriol. 177:3058-3066.

20. Encarnación, S., and J. Mora. Unpublished data.

21. Espín, G., S. Moreno, and J. Guzmán. 1994. Molecular genetics of the glutamine synthetases in Rhizobium species. Crit. Rev. Microbiol. 20:117123 .

22. Fuchs, R. L., and D. L. Keister. 1980. Identification of two glutamine synthetases in Agrobacterium. J. Bacteriol. 141:996-998.

23. Geniaux, E., M. Flores, R. Palacios, and E. Martínez. 1995. Presence of megaplasmids in Rhizobium tropici and further evidence of differences between two R. tropici subtypes. Int. J. Syst. Bacteriol. 45:392-394.

24. Graham, P. H., M. J. Sadowsky, H. H. Keyser, Y. M. Barnet, R. S. Bradley, J. E. Cooper, D. J. De Ley, B. D. W. Jarvis, E. B. Roslycky, B. W. Strijjom, and J. P. W. Young. 1991. Proposed minimal standards for the description of new genera and species of root- and stem-nodulating bacteria. Int. J. Syst. Bacteriol. 41:582-587.

25. Hernández-Lucas, I., L. Segovia, E. Martínez-Romero, and S. G. Pueppke. 1995. Phylogenetic relationships and host range of Rhizobium spp. that nodulate, Phaseolus vulgaris L. Appl. Environ. Microbiol. 61:2775-2779.

26. Howitt, S. M., and P. M. Gresshoff. 1985. Ammonia regulation of glutamine synthetase in Rhizobium sp. ANU289. J. Gen. Microbiol. 131:1433-1440.

27. Huang, N., G. L. Stebbins, and R. L. Rodriguez. 1992. Classification and evolution of $\alpha$-amylase genes in plants. Proc. Natl. Acad. Sci. USA 89:75267530 .

28. Jarvis, B. D. W., H. L. Downer, and J. P. W. Young. 1992. Phylogeny of fast-growing soybean-nodulating rhizobia supports synonymy of Sinorhizobium and Rhizobium and assignment to Rhizobium fredii. Int. J. Syst. Bacteriol. 42:93-96.

29. Jarvis, B. D. W., and S. W. Tighe. 1994. Rapid identification of Rhizobium species based on cellular fatty acid analysis. Plant Soil 161:31-41.

30. Kumada, Y., D. R. Benson, D. Hilleman, T. J. Hosted, D. A. Rochefort, C. J. Thompson, W. Wohlleben, and Y. Tateno. 1993. Evolution of the glutamine synthetase gene, one of the oldest existing and functioning genes. Proc. Natl. Acad. Sci. USA 90:3009-3013.

31. Laemmli, U. K. 1970 . Cleavage of structural proteins during the assembly of the head of bacteriophage T4. Nature (London) 227:680-685.

32. Laguerre, G., M.-R. Allard, F. Revoy, and N. Amarger. 1994. Rapid identification of rhizobia by restriction fragment length polymorphism analysis of PCR-amplified 16S rRNA genes. Appl. Environ. Microbiol. 60:56-63.

33. Lindström, K., P. van Berkum, M. Gillis, E. Martinez, N. Novikova, and B. Jarvis. 1995. Report from the roundtable on Rhizobium taxonomy, p. 807810. In I. A. Tikhonovich, et al. (ed.), Nitrogen fixation: fundamentals and applications. Kluwer, Dordrecht, The Netherlands.

34. Ludwig, R. A. 1980. Physiological roles of glutamine synthetases I and II in ammonium assimilation in Rhizobium $\mathrm{sp}$. 32H1. J. Bacteriol. 141:1209-1216.

35. Manco, G., M. Rossi, R. Defez, A. Lamberti, G. Peruoco, and M. Iaccarino. 1992. Dissociation by $\mathrm{NH}_{4} \mathrm{Cl}$ treatment of the enzymatic activities of glutamine synthetase II from Rhizobium leguminosarum biovar viciae. J. Gen. Microbiol. 138:1453-1460.

36. Manian, S. S., and F. O'Gara. 1982. Induction and regulation of ribulose bisphosphate carboxylase activity in Rhizobium japonicum during formatedependent growth. Arch. Microbiol. 131:51-54.

37. Martin, G. B., and B. K. Chelm. 1991. Bradyrhizobium japonicum ntrBC/glnA and nifA/ginA mutants: further evidence that separate regulatory pathways govern ginII expression in free-living and symbiotic cells. Mol. Plant Microbe Interact. 4:254-261. 
38. Martínez, E., M. A. Pardo, R. Palacios, and M. A. Cevallos. 1985. Reiteration of nitrogen fixation gene sequences and specificity of Rhizobium in nodulation and nitrogen fixation in Phaseolus vulgaris. J. Gen. Microbiol. 131:1779-1786.

39. Martínez-Romero, E. 1994. Recents developments in Rhizobium taxonomy. Plant Soil 161:11-20.

40. Martínez-Romero, E., L. Segovia, F. M. Mercante, A. A. Franco, P. Graham, and M. A. Pardo. 1991. Rhizobium tropici, a novel species nodulating Phaseolus vulgaris L. beans and Leucaena sp. trees. Int. J. Syst. Bacteriol. 41:417426.

41. Meade, H. M., S. R. Long, G. B. Ruvkun, S. E. Brown, and F. M. Ausubel. 1982. Physical and genetic characterization of symbiotic and auxotrophic mutants of Rhizobium meliloti induced by transposon Tn5 mutagenesis. J. Bacteriol. 149:114-122.

42. Moreno, S., R. Meza, J. Guzmán, A. Carabez, and G. Espín. 1991. The glnA gene of Rhizobium leguminosarum bv. phaseoli and its role in symbiosis. Mol. Plant Microbe Interact. 4:619-622.

43. O'Farrel, P. H. 1975. High resolution two-dimensional electrophoresis of proteins. J. Biol. Chem. 250:4007-4021.

44. Patriarca, E. J., M. Chiurazzi, G. Manco, A. Riccio, A. Lamberti, A. de Paolis, M. Rossi, R. Defez, and M. Iaccarino. 1992. Activation of the Rhizobium leguminosarum glnII gene by $\mathrm{NtrC}$ is dependent on upstream DNA sequences. Mol. Gen. Genet. 234:337-345.

45. Pesole, G., M. P. Bozzetti, C. Lanave, G. Preparata, and C. Saccone. 1991. Glutamine synthetase gene evolution: a good molecular clock. Proc. Natl. Acad. Sci. USA 88:522-526.

46. Pesole, G., C. Gissi, C. Lavane, and C. Saccone. 1995. Glutamine synthetase gene evolution in bacteria. Mol. Biol. Evol. 12:189-197.

47. Piñero, D., E. Martínez, and R. K. Selander. 1988. Genetic diversity and relationships among isolates of Rhizobium leguminosarum biovar phaseoli. Appl. Environ. Microbiol. 54:2825-2832.

48. Priefer, U. B. 1989. Genes involved in lipopolysaccharide production and symbiosis are clustered on the chromosome of Rhizobium leguminosanum biovar viciae VF39. J. Bacteriol. 171:6161-6168.

49. Rao, V. R., R. A. Darrow, and D. L. Keister. 1978. Effect of oxygen tension on nitrogenase and on glutamine synthetases I and II in Rhizobium japoni- cum 61A76. Biochem. Bjophys. Res. Commun, 81:224-231.

50. Rigby, P. W. J., M. Dieckman, C. Rhodes, and P. Berg. 1976. Labeling deoxyribonucleic acid to a high specific activity in vitro by nick translation with DNA polymerase I. J. Mol. Biol. 113:237-251.

51. Rolfe, B. G., P. M. Gresshoff, and J. Shine. 1980. Rapid screening for symbiotic mutants of Rhizobium and white clover. Plant Sci. Lett. 19:277284.

52. Rossi, M., R. Defez, M. Chiurazzi, A. Lamberti, A. Fuggi, and M. Iaccarino. 1989. Regulation of glutamine synthetase isoenzymes in Rhizobium leguminosarum biovar viciae. J. Gen. Microbiol. 135:629-637.

53. Schofield, P. R., A. H. Gibson, W. F. Dudman, and J. M. Watson. 1987. Evidence for genetic exchange and recombination of Rhizobium symbiotic plasmids in a soil population. Appl. Environ. Microbiol. 53:2942-2947.

54. Segovia, L., D. Piñero, R. Palacios, and E. Martínez-Romero. 1991. Genetic structure of a soil population of nonsymbiotic Rhizobium leguminosanum. Appl. Environ. Microbiol. 57:426-433.

55. Segovia, L., J. P. W. Young, and E. Martínez-Romero. 1993. Reclassification of American Rhizobium leguminosarum biovar phaseoli type I strains as Rhizobium etli sp. nov. Int. J. Syst. Bacteriol. 43:374-377.

56. Shatters, R. G., and M. L. Kahn. 1989. Glutamine synthetase II in Rhizobium: reexamination of the proposed horizontal transfer of DNA from eukaryotes to prokaryotes. J. Mol. Evol. 29:422-428.

57. Shatters, R. G., J. E. Somerville, and M. L. Kahn. 1989. Regulation of glutamine synthetase II activity in Rhizobium meliloti 104A14. J. Bacteriol. 171:5087-5094.

58. Souza, V., T. T. Nguyen, R. R. Hudson, D. Piñero, and R. E. Lenski. 1992. Hierarchical analysis of linkage disequilibrium in Rhizobium populations: evidence for sex? Proc. Natl. Acad. Sci. USA 89:8389-8393.

59. Towbin, H., T. Staehelin, and J. Gordon. 1979. Electrophoretic transfer of proteins from polyacrylamide gels to nitrocellulose sheets: procedure and some applications. Proc. Natl. Acad. Sci. USA 76:4350-4354.

60. Walker, J. M., and W. Gaastra. 1988. Detection of protein blots using enzyme-linked second antibodies or protein A, p. 427-440. In J. M. Walker (ed.), Methods in molecular biology. Humana Press, Clifton, N.J.

61. Woese, C. R. 1987. Bacterial evolution. Microbiol. Rev. 51:221-271. 